\title{
The language of god: a scientist presents evidence for belief
}

Volume 7 Issue I - 2017

\section{Opinion}

Today, we are learning the language in which God created life. We are gaining evermore awe for the complexity, the beauty and the wonder of God's most divine and sacred gift. -- President Bill Clinton (as quoted on page 2 of the book).

Francis Collins was with President Clinton in the East Room of the White House at this announcement that the total human genome had been mapped. From the president of the Human Genome Project, Collins' book, The Language of God, is a witness to his beliefs about God which coincide, quite frankly, with most believers in one way or another.

If you have a scientific background, much new will not likely be found. Still, astounding complexity is repeated and given succor as an evolutionary process per the author. The origins of the universe, microbes to man, genesis, Galileo, Darwin, atheism, agnosticism, creationism, and intelligent design, all receive their analyses. He proposes "bioLogos" as a "science and faith in harmony" effort to settle matters between believers and scientists who do not believe.

I was disappointed in his analysis of "suffering" (Pages 42-47 and 231-232), and I quote from my own "The Theogeocalculus of Life (Linacre Quarterly, August, 2006) maintaining that God's perfection must allow suffering:

Suffering exists because of freedom. God's perfection gives freedom to choose and in that perfection the extremes of choosing from ultimate transcendental living to ultimate non-being (evil) will occur, because the choices of freedom require a polarity from God to satan (or simplistically, from good to bad). Therefore, Satan and evil exist for $\mathrm{C} 2 \mathrm{CCs}$ Conscious of consciousness capable creature)who have freedom. Such is the perfection of God. To be free, we have to choose and the choices must range from one extreme to the other or "choice" (and freedom) is meaningless.

About evolution, Collins' enthusiasm is clear, cogent, and naturally confirmed, he maintains, by genetics. He points out that two intermediate sized chimp chromosomes can be fused to render a marked similarity between human and chimp karyotypes (Pg. 137) thus proving evolution. (1, of course, offer something even better and more obvious which everyone can see: two feet! "B. ality" means that man evolved from birds -- and I will let you decide what has happened to the feathers). Collins believes that similarities of genetic composition across species are equivalent to kindredness for living creatures, an idea which is circumstantial and undiscreditable, because this is to demand that God not allow redundancies or "junk DNA." The "junk DNA" commonality of humans and mice (Pg. 137) rejects entropy as possible for God's language and demands that God be more precise in distinguishing his creatures (One might demand that there be more than four suits in a deck of cards as well as more than four amino acids in the language of God).

After rightfully disdaining the idea of "God of the gaps" for believers, he imposes a "science of the gaps" when he maintains

\author{
Samuel A Nigro M.D \\ Retired, Assistant Clinical Professor Psychiatry, Case Western \\ Reserve University School of Medicine, USA
}

Correspondence: Dr. Samuel A Nigro M.D., Retired,Assistant Clinical Professor Psychiatry, Case Western Reserve University School of Medicine, 2517 Guilford Road, Cleveland Heights, Ohio 44I 18, USA, Tel 216 932-0575, Email sam@docnigro.com

Received: June 20, 2016 | Published: February 06, 2017

that variations of proteins are equivalent to the variations of species postulated by Darwin. Finally, the philosophical deficiencies of "species" without understanding "essence" are never addressed, i.e., the author has never read Larry Lazar's Evolution and Other Fairy Tales. (About evolution, I observed that there are just too many monkeys running around to believe that it has happened yet. I do think it would be a good idea, however).

Most disturbing is that he does not engage the hypothesis that light itself is slowing down-- a phenomenon that has been alluded to but buried, censored and suppressed by scientists everywhere. But if the universe had a "big bang" beginning including light, such would reasonably suggest a slowing down of everything, including light!

Hubble found that everywhere he looked the light in the galaxies suggested they were receeding from ours. The farther away they were, the faster the galaxies were receeding (Pg. 64).

\section{Or, maybe light is just slowing down?}

One way to reduce the eons of history into a more comprehensible form is to imagine what would happen if the 4.5 billion years of the earth's existence, from initial formation to today, were instead compressed into a 24 hour day. If the earth was formed at 12:01 a.m. then life would appear at about 3:30 a.m. After a long day of slow progression to multicellular organisms, the Cambrian explosion would finally occur at about 9 p.m. Later that evening, dinosaurs would roam the earth. Their extinction would occur at 11:40 p.m., at which time the mammals would begin to expand...the divergence of branches leading to chimps and humans would occur with only 1 minute and 17 seconds remaining in the day, and anatomically modern humans would appear with just three seconds left. The life of a middle-aged human on earth today would occupy only the last millisecond (1/1000ths of a second). It is not surprising that many of 
us have a great deal of difficulty contemplating evolutionary time. (P. 148)

In light of the reasoned slowing of speed of light (that's punny), the outcome becomes astonishing -- instead of the universe in 24 hours, try 6,000 years. It is too bad that this fun aspect of science continues to be suppressed.

On a positive note, I learned that Buzz Aldrin of Apollo 11 arranged to take communion on the surface of the moon during the first landing in 1969, but that event was never published (Pg. 160). And he reminds that "no one objected in 1844 when Samuel Morse's first telegraph message was "What has God wrought?" (Pg. 160).

This is a good book and a favorable contribution for us believers. Still, with some conceit, I apologetically offer my article "The Self
Aware Universe: A Theological Meditation" Social Justice Review September/October 2006 Pg. 136-139.

\section{Acknowledgments}

None.

\section{Conflicts of interest}

None.

\section{Funding}

None. 